\title{
Correlation between Family Support and Self Care in Type 2 Diabetes Mellitus: Meta-Analysis
}

\author{
Dian Dini Islami'), Didik Gunawan Tamtomo'), Hanung Prasetya ${ }^{3)}$ \\ 1)Masters Program in Public Health, Universitas Sebelas Maret \\ 2)Faculty of Medicine, Universitas Sebelas Maret \\ 3)Study Program in Acupuncture, Health Polytechnics Ministry of Health Surakarta
}

\section{ABSTRACT}

Background: Patients with Type 2 Diabetes Mellitus have a high risk of serious complications. Complications resulting from diabetes can be minimized and prevented by implementing self-care behavior. The study revealed that one of the factors that affect self-care activity is family support. The correlation of family support with self-care activity has been extensively investigated in several primary studies with several contradictions in the results. This study aimed to determine the correlation between family support and self-care activity in people with type 2 diabetes mellitus using the meta-analysis method.

Subjects and Method: This study was a systematic review and meta-analysis. The metaanalysis was carried out by systematically reviewing articles published from 2010 to 2020 from the Pubmed, Google Scholar, DOAJ, and Springer Link databases using search keywords, namely ("Family Support" OR "Social Support") AND ("Self Management "OR" Self Care ") AND" Diabetes Mellitus Type 2". Article searches were carried out using PICO. The study population was people with type 2 diabetes mellitus. Intervention/exposure was getting family support compared to not getting family support, and the outcome was diabetes mellitus self-care. The search for articles was carried out for one month. The articles included in this study were full-text articles with a crosssectional design. Articles were reviewed using the PRISMA flow diagram guidelines. Articles analyzed using Revman 5.3 Software.

Conclusion: People with type 2 diabetes mellitus with good family support will increase self-care activity 2.22 times compared to people with type 2 diabetes mellitus who do not get family support. ( $\mathrm{aOR}=2.22$ (95\% CI $=1.84$ $2.68 ; \mathrm{p}<0.001$ ) The study of 7 articles originated from Africa.

Keywords: family support, self-care, diabetes mellitus type 2

\section{Correspondence:}

Dian Dini Islami. Masters Program in Public Health, Universitas Sebelas Maret. Jl. Ir. Sutami 36A, Surakarta 57126, Central Java, Indonesia. Email: dian.dinii94@gmail.co. Mobile: 085729483960.

\section{Cite this as:}

Islami DD, Tamtomo DG, Prasetya H (2021). Correlation between Family Support and Self Care in Diabetes Mellitus Type 2: Meta-Analysis. Indones J Med. 06(01): 62-70. https://doi.org/10.26911/theijmed.2021.06.01.07.

\section{cc (i) (-) Indonesian Journal of Medicine is licensed under a Creative Commons cc) Attribution-NonCommercial-ShareAlike 4.0 International License.}

BACKGROUND
Diabetes mellitus is a chronic condition
characterized by an increase in blood glu-
cose concentration accompanied by the
appearance of a characteristic main symp-
tom, namely urine containing glucose. The
disorder that is the fundamental cause of

diabetes mellitus is a relative or absolute deficiency of the body's insulin hormone (Bilous \& Donelly, 2015). Patients with diabetes mellitus have a high risk of experiencing serious complications. Increased blood sugar that lasts a long time will be bad for people with diabetes mellitus itself. 
Complications of diabetes mellitus also have a negative impact on the lives of people with Diabetes Mellitus, both physically, psychologically, socially, and economically. A study conducted by Garousi (2013) stated that diabetes mellitus is a chronic metabolic disease that requires good attention from sufferers and their families. Complications resulting from diabetes can be minimized and prevented by controlling blood sugar and implementing self-care management behavior (Vaccaro et al., 2014).

Self-care for diabetes mellitus sufferers is considered to be an important part. Other studies reveal that self-care activity in type $2 \mathrm{DM}$ patients can improve the condition of diabetes mellitus patients and can prevent and reduce long-term complications in patients (Alrahbi, 2014). This is in line with a study conducted by Kisokanth et al. (2013), which stated that diabetes self-care activity could optimize sufferers to control metabolism, prevent acute and chronic complications, and improve the quality of life of people with Diabetes Mellitus. Similar research also reveals that good self-care management can reduce the risk of complications and reduce the incidence of hospitalization and mortality due to Diabetes Mellitus (Mayberry \& Osborn, 2012).

Several factors can affect self-care in diabetes mellitus patients, including age, length of suffering from diabetes mellitus, knowledge, spirituality, self-efficacy, social support, social-environmental support, and social problem-solving.

According to other studies, self-care management is affected by several factors. One of the most influential factors is family support (Damayanti, 2014, in Hidayati, 2017). Family is the closest social environment to diabetes mellitus perpetrators, so it is hoped that it can help control and shape the behavior of diabetics to do self-care.
The researcher is interested in studying the correlation between family support and self-care activity in diabetes mellitus sufferers, especially type 2 diabetes mellitus. The data obtained will be analyzed using meta-analysis by synthesizing the results.

\section{SUBJECTS AND METHOD}

\section{Study Design}

This was a systematic review and meta-analysis. The meta-analysis was conducted by systematically reviewing articles published from 2010 to 2020 from the Pubmed, Google Scholar, Springer Link, and DOAJ databases using search keywords, namely ("Family Support" OR "Social Support") AND ("Self Management "OR" Self Care") AND" Diabetes Mellitus Type 2 ".

\section{Inclusion Criteria}

The author developed inclusion criteria, namely full-text articles in English and Indonesian, with a cross-sectional study design. Study subjects with type 2 diabetes mellitus were aged 18 to $>18$ years. The outcome analyzed was self-care. The analysis used multivariate with adjusted odds ratio and outcomes is Self Care.

\section{Exclusion Criteria}

This study's exclusion criteria were nonobservational research; articles were not full text and published before 2010. Articles published in languages other than English, Indonesian, and not a multivariate analysis study.

\section{Operational Definition of Variables}

The article search was carried out by considering the eligibility criteria defined using the PICO model. The study population was T2DM patients, with intervention having family support, comparison, namely not getting family and the outcome was selfcare.

Family support was the attitude of action and family acceptance of family 
members, informational support, assessment support, instrumental support, and emotional support. The measurement instrument used a questionnaire with a categorical scale.

Diabetes Mellitus self-care was implementing individual activities related to fulfilling needs in maintaining life, health, and well-being. The instrument for measuring the SDSCA questionnaire (Summary Diabetes Self-Care Activities) using a categorical scale.

\section{Data Analysis}

Articles were collected using PRISMA diagrams. Data analysis was performed using the Software Review Manager (RevMan)
5.3 published by the Cochrane Collaboration. RevMan was used to calculate the overall adjusted Odds Ratio (aOR), describing the 95\% confidence interval (CI) using the effects model, as well as $\mathrm{I}^{2}$ or data heterogeneity.

\section{RESULTS}

The process of reviewing articles can be seen in the PRISMA flow diagram Figure 1. This meta-analysis analyzed seven primary studies conducted in Ethiopia, Africa.

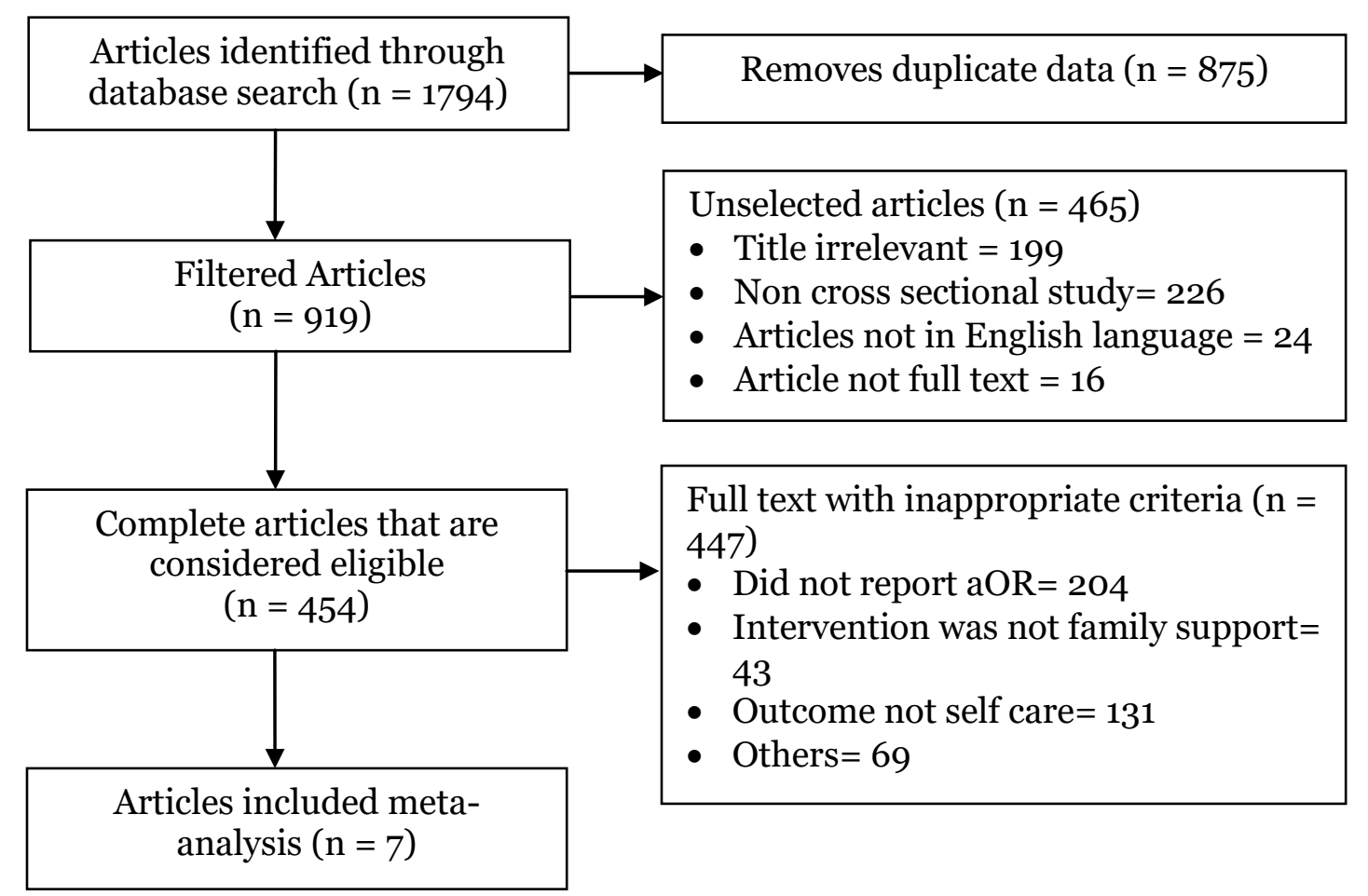

Figure 1. PRISMA flow diagram 
Table 2.Description of primary studies included in the meta-analysis of the correlation between family support and self-care in people with type 2 diabetes mellitus

\begin{tabular}{|c|c|c|c|c|c|c|}
\hline $\begin{array}{l}\text { Author } \\
\text { (year) }\end{array}$ & Title & Location & $\begin{array}{l}\text { Study } \\
\text { Design }\end{array}$ & $\begin{array}{c}\text { Samples and } \\
\text { Study Subjects }\end{array}$ & $\begin{array}{l}\text { Intervention (I) } \\
\text { and comparison } \\
\text { (C) }\end{array}$ & Outcome \\
\hline $\begin{array}{l}\text { Diriba et al. } \\
(2020)\end{array}$ & $\begin{array}{l}\text { Predictors of self-management } \\
\text { practices among diabetic patients } \\
\text { attending hospitals in western } \\
\text { Oromia, Ethiopia }\end{array}$ & $\begin{array}{l}\text { Northwestern } \\
\text { Ethiopia (Continent } \\
\text { of Africa) }\end{array}$ & $\begin{array}{l}\text { Cross- } \\
\text { Sectional }\end{array}$ & $\begin{array}{l}\text { Sample: } 400 \mathrm{DM} \\
\text { patients with a } \\
\text { mean age of } 41.33 \\
\pm 18.93\end{array}$ & $\begin{array}{l}\text { I: Always get family } \\
\text { support, C: Do not } \\
\text { always get family } \\
\text { support }\end{array}$ & $\begin{array}{l}\text { Self } \\
\text { Management }\end{array}$ \\
\hline $\begin{array}{l}\text { Gee et al. } \\
(2020)\end{array}$ & $\begin{array}{l}\text { Self-care practice and associated } \\
\text { factors among adult diabetic } \\
\text { patients in public hospitals of } \\
\text { Dire Dawa administration } \\
\text { Eastern Ethiopia }\end{array}$ & $\begin{array}{l}\text { Eastern Ethiopia } \\
\text { (African Continent) }\end{array}$ & $\begin{array}{l}\text { Cross- } \\
\text { Sectional }\end{array}$ & $\begin{array}{l}\text { Sample: } 513 \text { adult } \\
\text { DM patients }\end{array}$ & $\begin{array}{l}\text { I: Having family } \\
\text { support, } \\
\text { C: Not having family } \\
\text { support }\end{array}$ & Self Care \\
\hline $\begin{array}{l}\text { Gulentie et } \\
\text { al. (2020) }\end{array}$ & $\begin{array}{l}\text { Predictors of diabetes self care } \\
\text { practice among patients with type } \\
2 \text { diabetes in public hospitals in } \\
\text { Northeastern Ethiopia: A Facility- } \\
\text { Based Cross-sectional Study }\end{array}$ & $\begin{array}{l}\text { Northeast Ethiopia } \\
\text { (Continent of Africa) }\end{array}$ & $\begin{array}{l}\text { Cross- } \\
\text { Sectional }\end{array}$ & $\begin{array}{l}\text { Sample: } 403 \text { types } \\
\text { two diabetes } \\
\text { mellitus patients } \\
\text { with mean age } 46.7 \\
\pm 11.3\end{array}$ & $\begin{array}{l}\text { I: Having social } \\
\text { support (family, } \\
\text { friends), C: Not } \\
\text { having social } \\
\text { support (family, } \\
\text { friends) }\end{array}$ & Self Care \\
\hline $\begin{array}{l}\text { Gurmu et } \\
\text { al. (2018) }\end{array}$ & $\begin{array}{l}\text { Factors associated with self-care } \\
\text { practice among adult diabetes } \\
\text { patients in West Shoa Zone, } \\
\text { Oromia Regional State, Ethiopia }\end{array}$ & $\begin{array}{l}\text { West Shoa Zone, } \\
\text { Ethiopia (Africa } \\
\text { Continent) }\end{array}$ & $\begin{array}{l}\text { Cross- } \\
\text { Sectional }\end{array}$ & $\begin{array}{l}\text { Sample: } 257 \text { adult } \\
\text { DM patients aged } \\
18 \text { and }>18 \text { years }\end{array}$ & $\begin{array}{l}\text { I: Getting good } \\
\text { social support, C: } \\
\text { Getting poor social } \\
\text { support }\end{array}$ & Self Care \\
\hline $\begin{array}{l}\text { Mamo et al. } \\
(2016)\end{array}$ & $\begin{array}{l}\text { Self care practice and its asso- } \\
\text { ciated factors among diabetic } \\
\text { patients in Addis Ababa Public } \\
\text { Hospitals, cross-sectional study }\end{array}$ & $\begin{array}{l}\text { Addis Ababa, } \\
\text { Ethiopia (Continent } \\
\text { of Africa) }\end{array}$ & $\begin{array}{l}\text { Cross- } \\
\text { Sectional }\end{array}$ & $\begin{array}{l}\text { Sample: } 600 \mathrm{DM} \\
\text { patients aged 18- } \\
80 \text { years }\end{array}$ & $\begin{array}{l}\text { I: Getting social } \\
\text { support (family, } \\
\text { friends), C: Lacking } \\
\text { of social support } \\
\text { (family, friends) }\end{array}$ & Self-care \\
\hline $\begin{array}{l}\text { Tiruneh et } \\
\text { al. (2018) }\end{array}$ & $\begin{array}{l}\text { Factors influencing diabetes self- } \\
\text { care practice patients attending } \\
\text { diabetic care follow up at Hospital }\end{array}$ & $\begin{array}{l}\text { Northwestern } \\
\text { Ethiopia (Continent } \\
\text { of Africa }\end{array}$ & $\begin{array}{l}\text { Cross- } \\
\text { Sectional }\end{array}$ & $\begin{array}{l}\text { Sample: } 385 \text { type } 2 \\
\text { DM patients aged } \\
>18 \text { years }\end{array}$ & $\begin{array}{l}\text { I: Getting social } \\
\text { support, C: Not } \\
\text { getting social } \\
\text { support }\end{array}$ & Self-care \\
\hline
\end{tabular}


Islami et al./ Correlation between Family Support and Self Care in Type 2 DM

\begin{tabular}{|c|c|c|c|c|c|c|}
\hline $\begin{array}{c}\text { Author } \\
\text { (year) }\end{array}$ & Title & Location & $\begin{array}{c}\text { Study } \\
\text { Design }\end{array}$ & $\begin{array}{c}\text { Samples and } \\
\text { Study Subjects }\end{array}$ & $\begin{array}{l}\text { Intervention (I) } \\
\text { and comparison } \\
\text { (C) }\end{array}$ & Outcome \\
\hline $\begin{array}{l}\text { Wehabrebi } \\
\text { et al. } \\
\text { (2020) }\end{array}$ & $\begin{array}{l}\text { Diabetes self-care practice, and } \\
\text { associated factors among type } 2 \\
\text { diabetic patients in public } \\
\text { hospitals of Tigray Region, } \\
\text { Ethiopia }\end{array}$ & $\begin{array}{l}\text { Tigray Regional } \\
\text { Hospital, Ethiopia } \\
\text { (African Continent) }\end{array}$ & $\begin{array}{l}\text { Cross- } \\
\text { Sectional }\end{array}$ & $\begin{array}{l}\text { Sample: } 576 \text { type } 2 \\
\text { DM patients aged } \\
\geq 18 \text { years }\end{array}$ & $\begin{array}{l}\text { I: Having family } \\
\text { support, } \\
\text { C: Not having family } \\
\text { support }\end{array}$ & Self-care \\
\hline
\end{tabular}


Islami et al./ Correlation between Family Support and Self Care in Type 2 DM

\section{a. Forest plot}

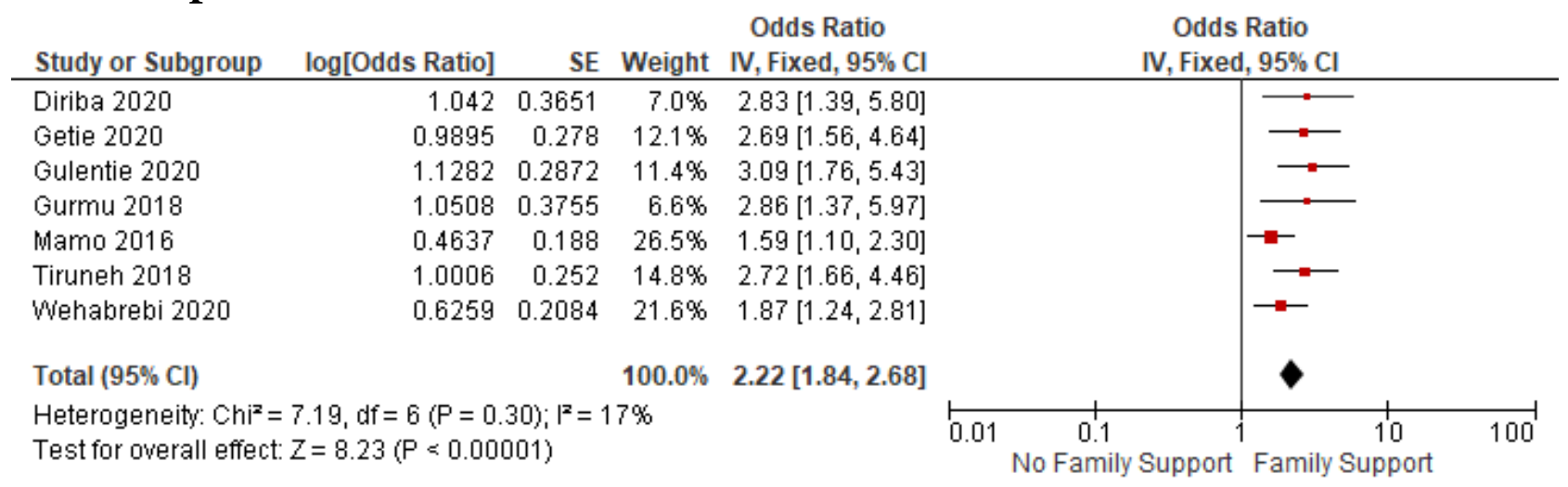

Figure 3. Forest plot of the correlation between family support and self -care activity for Patients with Type 2 Diabetes Mellitus

\section{b. Funnel plot}

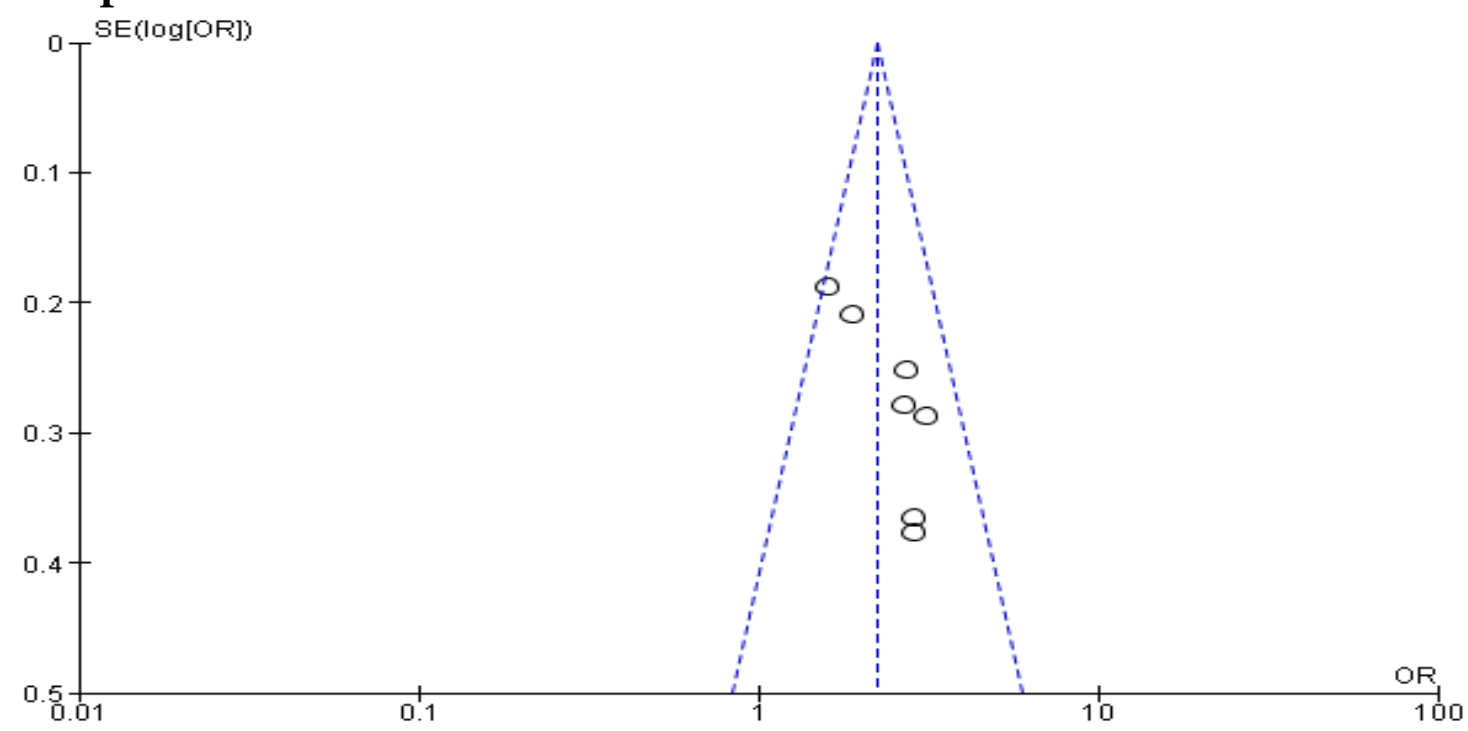

Figure 4. Funnel plot of the correlation between family history of DM and the incidence of gestational diabetes mellitus

The forest plot shows that type 2 diabetes mellitus sufferers who get good family support would increase the risk of practicing self-care activity 2.22 times compared to type 2 diabetes mellitus sufferers who did not get family support, the results of $95 \% \mathrm{CI}=1.84-2.68$ and significantly statistically evidenced by value $(\mathrm{p}<0.001)$. The study data analysis results showed $\mathrm{I}^{2}=$ $17 \%$ so that the distribution of data was declared homogeneous (fixed-effect model).
The funnel plot showed an asymmetrical distribution of the research. The distribution of the research was not balanced on the left and right of the centerline boundary. On the left, there weretwo plots, and on the right, there were five plots. Bias also occurred from the imbalance between the distance between the studies on the right and the left of the funnel plot. The plot on the left of the graph appears to have a standard error between 
0.2 and 0.3 , and the plot on the right of the graph appeared to have a standard error between 0.2 and 0.4 . So it can be concluded that publication bias affected the correlation between family support and self-care in people with type 2 diabetes mellitus.

\section{DISCUSSION}

This study was a systematic study and meta-analysis with the theme of the correlation between family support and self-care for diabetes mellitus type 2. The independent variable analyzed was family support. The dependent variable studied was Diabetes Mellitus self-care. A study that discusses data on self-care for diabetes mellitus type 2 is considered important because, in addition to the number of relevant studies published and accessible, it is still small and also has data access problems (data duplication) (Murti, 2018).

Most reported statistical results from primary studies are in the number of a percent or odd crude ratio (cOR). The study did not control for confounding factors. Whereas the meta-analysis study used research that controls the confounding factor, which can be seen from the study's inclusion requirements, namely multivariate analysis, and the statistical result reported is the adjusted odds ratio (aOR).

Estimates of the combined relationship between family support and self-care for diabetes mellitus type 2 were processed using the RevMan 5.3 application with the generic inverse-variance method. This method is used to analyze data in the form of rate, time-to-event, hazard ratio, ordinal scale, adjusted estimate, the difference of meanor ratio of the mean.

The systematic study and meta-analysis results were presented in the form of a forest plot and a funnel plot. Forest plots show a large variation in heterogeneity (Akobeng, 2005 in Murti, 2018) visually).
The funnel plot shows the correlation between the study's effect size and the sample size of the various studies studied, which can be measured in several different ways (Murti, 2018). Funnel plots can be assessed from the study's asymmetry, which includes the number of points on the right and left sides compared to the standard error and a balance of the number of studies on the right and left (D'Souza et al., 2002).

\section{Family Support and Self Care}

The forest plot results show that people with type 2 diabetes mellitus who have family support have an increased risk of doing self-care by 2.22 times compared to people with type 2 diabetes mellitus who do not have family support. This result proved statistically significant $(\mathrm{aOR}=2.22 ; 95 \%$ $\mathrm{CI}=1.84$ to $\left.2.68 ; \mathrm{p}<0.001 ; \mathrm{I}^{2}=17 \%\right)$.

In this study, there are several differences found in each article used; numbers show risk factors and protective factors caused by several things, including differences in the number of samples in each article, differences in controlling confounding factors, so that is one of the reasons. The occurrence of bias. Also, the article's errors cannot be corrected and controlled because this study is secondary. In contrast, a secondary researcher can only examine the results that have been there before. This is what makes this study have limitations that cannot be overcome.

Family support is one of the important factors for diabetes mellitus sufferers to carry out self-care. This was revealed by Prasetyani et al., 2018 which proved that there was a correlation between family support and self-care for DM patients with results $(\mathrm{p}=0.000)$ with a strong correlation $(\mathrm{r}=0.671)$. This is in line with $\mathrm{s}$ study conducted by Pamungkas et al., 2017 which aimed to review and describe the impact of diabetes self-care education involving 
family members on patient outcomes related to patient health behaviors such as medication adherence, monitoring blood glucose, changes in diet and exercise, wellbeing. Psychological and self-efficacy and physiological markers, including body mass index, blood pressure, cholesterol levels, and glycemic control, reveal the results of developing diabetes interventions with family support are integral to maintaining self-care behavior and improving the health outcomes of type 2 diabetes patients.

Another epidemiological study conducted in Ethiopia revealed that $45.7 \%$ of diabetic patients had poor self-care practices, one of which did not have social support (family, friends, relatives) as evidenced by statistics (aOR $=1.84,95 \% \mathrm{CI}=$ 1.08-3.13; $\mathrm{p}=0.023$ ) (Chali et al., 2018). Diabetes mellitus sufferers who do not have family support will have bad self-care practices, so if self-care is poor, complications will occur in diabetes mellitus. This was revealed in a study by Mehravar et al., 2016 conducted in Iran, which aimed to determine the correlation between self-care and microvascular complications (retinopathy, nephropathy, and neuropathy) in type 2 diabetes patients. The results revealed a significant correlation between the scale of the number of self. Low diabetes care with high rates of neuropathy and nephropathy $(p=0.09)$.

\section{AUTHOR CONTRIBUTION}

Dian Dini Islami was the main researcher who selected the topic, explored, and collected study data. Didik Gunawan Tamtomo and Hanung Prasetya played a role in guiding the writing and reviewing of research documents.

\section{CONFLICT OF INTEREST}

There is no conflict of interest in this study.

\section{FUNDING AND SPONSORSHIP}

This study used private funds from the main researcher.

\section{ACKNOWLEDGEMENT}

The author would like to express their gratitude to PubMed, DOAJ, Springer Link, and Google Scholar.

\section{REFERENCE}

Alrahbi H (2014). Diabetes self-management (DSM) in Omani with type-2 diabetes. Int J Nurs Stud. 1(4): 352359. https://doi.org/10.1016/j.ijnss.2014.09.002.

Bilous R, Donelly R (2015). Buku Pegangan Diabetes (Ke-4). Bumi Medika.

Chali SW, Salih MH, Abate AT (2018). Selfcare practice and associated factors among Diabetes Mellitus patients on follow up in Benishangul Gumuz Regional State Public Hospitals, Western Ethiopia: A cross-sectional study. BMC Res Notes. 11: 833. https://doi.org/10.1186/s13104-018-3939-8

D’Souza AL, Rajkumar C, Cooke J, Bulpitt CJ (2002). Probiotics in prevention of antibiotic-associated diarrhoea: Metaanalysis. BMJ. 324(7350): 1361. https://doi.org/10.1136/bmj.324.7350.1361.

Garousi S (2013). Does perceived family support has a relation with depression and anxiety in an Iranian Diabetic Sample?. Int J Caring Sci, 6(3): 360368.

Hidayati L (2017). Hubungan dukungan keluarga dengan self management pada penderita diabetes mellitus tipe 2. Thesis. Universitas Muhammadiyah Yogyakarta: Faculty of Medicine and Health Science.

Kisokanth G, Prathapan S, Indrakumar J, Joseph P (2013). Factors influencing self-management of Diabetes Melli- 
tus; A review article. J Diabetol. 4(3): 6.

Mayberry LS, Osborn CY (2012). Family support, medication adherence, and glycemic control among adults with type 2 diabetes. Diabetes Care. 35(6): 1239-45. https://doi.org/10.2337/dc11-2103.

Mehravar F, Mansournia MA, HolakouieNaieni K, Nasli-Esfahani E, Mansournia N, Almasi-Hashiani A (2016). Associations between diabetes selfmanagement and microvascular complications in patients with type 2 diabetes. Epidemiol Health. 38: e2016004. https://doi.org/10.4178/epih/e2016004.

Murti B (2018). Prinsip dan Metode Riset Epidemiologi. Karanganyar: Bintang Fajar Offset.

Pamungkas RA, Chamroonsawasdi K, Vatanasomboon $P$ (2017). A systematic review: Family support integrated with diabetes self-management among uncontrolled type II diabetes mellitus patients. Behav Sci (Basel). 7(3): 62. https://doi.org/10.3390/bs7030062.

Prasetyani D, Apriani E, Rahayu YSE (2018). Hubungan karakteristik, pengetahuan dan dukungan keluarga dengan kemampuan self-care pada pasien dm tipe 2 di Puskesmas Cilacap Tengah 1 dan 2. Jurnal Kesehatan Al-Irsyad. 9(1): 40-49.

Vaccaro JA, Exebio JC, Zarini GG, Huffman FG (2014). The role of family/friend social support in diabetes self-management for minorities with type 2 diabetes. J Nutr Health. 2(1): 1-9. https://doi.org/10.12691/jnh-2-1-1. 